\title{
BATASAN NAFKAH YANG WAJIB DISERAHKAN SEORANG SUAMI KEPADA ISTRI
}

\author{
Armansyah, M.H. \\ Sekolah Tinggi Ilmu Syari'ah (STIS) AL-Amin Bima \\ armansyah19.boro@gmail.com
}

\section{Abstrak}

Pernikahan dalam Islam adalah sebuah ikatan bathin yang sangat sakral antara seorang suami dan istri, dengan ikatan pernikahan sesuatu yang awalnya bersifat haram untuk dilihat atau dilakuakan menjadi sesuatu yang boleh bahkan mendapat pahala dihadapan Allah Swt. Namun dengan ikatan pernikahan pula, sebuah hak dan kewajiban antara suami dan istri mulai ada. Dalam beberapa kitab literatur, disebutkan bahwa kewajiban seorang istri terhadap suami terbagi menjadi dua kategori; kewajiban primer (utama) dan sekunder. Kewajiban utama adalah sebuah kewajiban yang tidak boleh digantikan oleh siapapun, kecuali oleh sang istri, seperti melayani suami ditempat tidur. Sedangkan kewajiban sekunder adalah kewajiban yang boleh digantikan orang lain ketika istri tidak mampu atau adaanya sebuah uzur, seperti memasak, mencuci, membersihkan rumah dan lain sebagainya. Kewajiban sekunder ini sederhananya boleh dikerjakan oleh pembantu rumah tangga atau siapapun yang dipercaya. Demikian halnya seorang suami memiliki kewajiban yang sama, kewajiban utama dan sekunder. Dalam kitab "Al Adzakar" karya Imam al Nawawi disebutkan, setidaknya ada lima kewajiban utama seorang suami; baik lahir, yaitu menyediakan tempat tinggal, pakaian dan kebutuhan makan dan minumnya, sedangkan kewajiban secara bathin, 
yaitu perhatian dan pendidikan. Dari sederet permasalahan yang terjadi di tengah kehidupan masyarakat, yang paling dan sering dibicarakan adalah kewajiban seorang suami dalam hal keuangan ataupun terkait materi yang diserahkan oleh suami kepada sang istri. Karena kurangnya pengetahuan, terkadang seorang istri atau suami bahkan menganggap bahwa semua hasil usaha yang diperolehnya dari pekerjaan, wajib diserahkan kepada sang istri sebagai nafkah, sehingga seringkali ketika sang suami membutuhkan sesuatu, harus meminta izin dari sang istri dahulu terlebih uang telah dipegang oleh sang istri.

\section{Keyword: Nafkah, Batasan Nafkah, Suami Istri, Tanggungjawab.}

\section{A. Pendahuluan}

Ketika seorang laki-laki sebagai calon suami mengucapkan kalimat ijab qabul dalam pernikahan dihadapan calon mertua, dengan demikian maka secara otomatis pula menerima beban dan kewajiban sebagai seorang suami. Selain menerima segala kelebihan yang dimiliki oleh pasangan, demikian dengan segala kekurangan yang ada. Kendatipun seorang istri memiliki seribu kekurangan, hak seorang istri tidak pernah berkurang, kewajiban seorang suami akan tetap di tuntut oleh Allah bahkan kalau istri tidak menuntut kepada suami sekalipun. Allah berfirman:

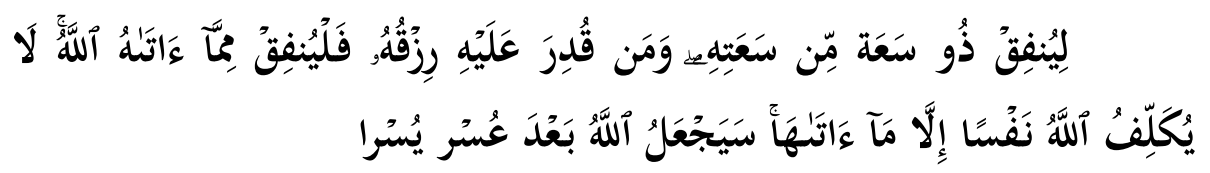

Terjemahnya:

"Hendaklah orang yang mampu memberi nafkah menurut kemampuannya. Dan orang yang disempitkan rezekinya hendaklah memberi nafkah dari harta yang diberikan Allah kepadanya. Allah tidak memikulkan beban kepada seseorang melainkan sekedar apa yang

Sangaji Jurnal Pemikiran Syariah dan Hukum 
Allah berikan kepadanya. Allah kelak akan memberikan kelapangan sesudah kesempitan." (QS. Al Thalaq: 7)

Berdasarkan ayat tersebut di atas dengan beberapa dalil lain, sepakat jumhur ulama tentang kewajiban menafkahi istri adalah merupakan tanggungan seorang suami. ${ }^{1}$ Tanggung jawab tersebut bersifat mutlak dan tidak tergantikan bahkan oleh orang tua sekalipun. Oleh karena itu, sebelum menikah seorang suami hendaknya memikirkan dan mengetahui tentang tanggung jawab yang akan dipikulnya sebelum mencari jodoh. Dan perintah Rasul mencari jodohpun ditujukan kepada yang telah dianggap mampu, sebagai dalam sabdanya:

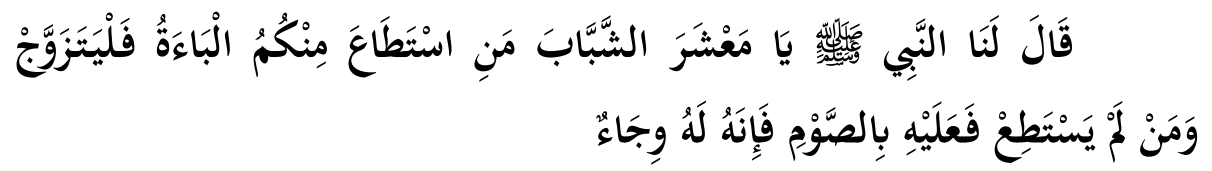

Artinya:

Nabi Saw. telah bersabda kepada kami: "Wahai sekalian pemuda, siapa di antara kalian yang telah mempunyai kemampuan, maka hendaklah ia menikah, dan barangsiapa yang belum mampu, hendaklah ia berpuasa karena hal itu akan lebih bisa meredakan gejolaknya." (HR. Al Bukhari dan Muslim)

Maka dalam tulisan singkat ini, penulis hendak menfokuskan pembahasan pada nafkah yang wajib diserahkan atau diberikan oleh seorang suami kepada istri berdasarkan dalil-dalil dari nash serta usaha orang tua terhadap membantu anak yang kesulitan dalam memberikan nafkah materi terhadap istri.

${ }^{1}$ Sayyid Sabiq. 2002. Fiqhu al Sunnah. Cetakan II. Kairo: Dar al Fikr. Hlm. 169-170. Lihat juga: Husein Muhammad. 2001. Figh Perempuan. Yogyakarta: LKis. Hlm. 123. Lihat juga: Abdul Aziz Dahlan. 1996. Ensklopedi Hukum Islam. Jakarta: PT. Ichtiar Baru. Hlm. 1281. 


\section{B. Pengertian}

Secara bahasa nafkah sebenarnya berasal dari bahasa

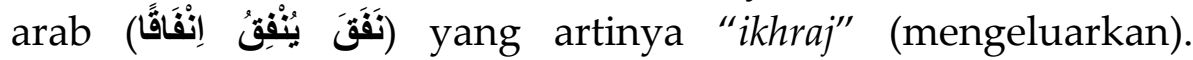
Sedangkan secara istilah nafkah adalah belanja untuk hidup; (uang) kepada istri; 2 rezeki; bekal hidup sehari-hari. ${ }^{2}$ Nafkah memiliki makna segala biaya hidup merupakan hak isteri dan anak-anak dalam hal makanan, pakaian dan tempat kediaman serta beberapa kebutuhan pokok lainnya, bahkan sekalipun si istri itu seorang wanita yang kaya. ${ }^{3}$

Sedangkan Menurut Amir syarifuddin dalam bukunya "Hukum Perkawinan Islam di Indonesia" nafkah menurut yang disepakati ulama adalah belanja untuk keperluan makan yang mencakup sembilan bahan pokok pakaian dan perumahan atau dalam bahasa sehari-hari disebut sandang, pangan dan papan. Selain dari tiga hal pokok tersebut jadi perbincangan dikalangan ulama. ${ }^{4}$

Definisi yang lebih umum lagi dirumuskan oleh Salim bin Abdu al Ghani al Rafi'i ${ }^{5}$ dengan menyebutkan bahwa istri yang berhak mendapat nafkah bukan saja yang berstatus muslimah, akan tetapi istri dari kalangan ahl al-kitâb pun berhak untuk mendapatkan nafkah tersebut, sebagaimana penjelasannya:

2 Tim Pusat Bahasa Depdiknas. 2008. Kamus Bahasa Indonesia. Jakarta: Pusat Bahasa Departemen Pendidikan Nasional. Hlm. 992.

3 Syamsul Bahri. 2015. Konsep Nafkah Dalam Hukum Islam. Kanun Jurnal Ilmu Hukum Nomor 66 Th. XVII Agustus 2015. Hlm. 382. Lihat juga: Abdurrahman. 1992. Perkawinan dalam Syari'at Islam. Cetakan I. Jakarta: Rineka Cipta. Hlm. 121.

4 Amir Syarifuddin. 2001. Hukum Perkawinan Islam di Indonesia. Cetakan II. Jakarta: Prenada Media. Hlm. 166.

5 Ahmad Rajafi. 2018. Reinterpretasi Makna Nafkah dalam Bingkai Islam Nusantara. Jurnal Al Ihkam Volume 13 Nomor 1 Juni 2018. Hlm. 103. Lihat juga: Salim bin Abdu al Ghani al Rafi'i. 2002. Ahkam al Ahwal al Syakhshiyyah li al Muslimin fi al Gharb. Beirut: Dar Ibn Hazm. Hlm. 476.

Sangaji Jurnal Pemikiran Syariah dan Hukum 


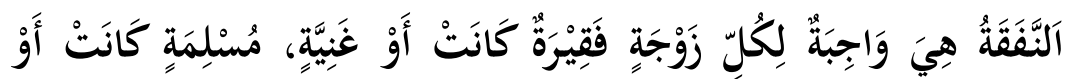

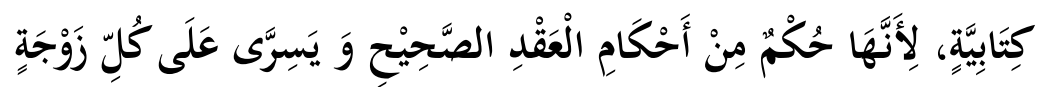

Artinya:

"Nafkah adalah sesuatu yang wajib diterima oleh istri, baik ia tergolong miskin ataupun kaya, muslimah ataupun ahli kitab, karena nafkah tersebut dikategorikan sebagai bagian dari hukum perikatan yang benar, dan berlaku kepada setiap istri."

Di dalam peraturan perundang-undangan di Indonesia tidak di atur secara eksplisit pengertian nafkah. Namun, yang memiliki maksud sama dengan nafkah itu sendiri secara implisit disebut dalam Pasal 34 ayat (1) UU No. 1 Tahun 1974 tentang Perkawinan (“UU Perkawinan”) yang berbunyi: "Suami wajib melindungi isterinya dan memberikan segala sesuatu keperluan hidup berumah tangga sesuai dengan kemampuannya"6

Selain merujuk pada UU Perkawinan, kewajiban suami/bapak dalam rumah tangga juga terdapat dalam Pasal 9 ayat (1) Undang-Undang Nomor 23 Tahun 2004 tentang Penghapusan Kekerasan Dalam Rumah Tangga (“UU PKDRT”) yang mengatakan bahwa setiap orang dilarang menelantarkan orang dalam lingkup rumah tangganya, padahal menurut hukumyang berlaku baginya atau karena persetujuan atau perjanjian wajib memberikan kehidupan, perawatan, atau pemeliharaan kepada orang tersebut. Anak merupakan orang dalam lingkup rumah tangga yang perlu dirawat dan dipelihara oleh orang yang menjadi penanggung baginya, dalam hal ini adalah bapak. Oleh karena, itu, secara undangundang, seorang bapak berkewajiban memberikan nafkah bagi anak. $^{7}$

\footnotetext{
${ }^{6}$ Lihat: UU Nomor 1 Tahun 1974 tentang Perkawinan Pasal 34 ayat 1.

7 Tri Jata Ayu Pramesti. 2013. Batasan Antara Nafkah dan Uang Jajan. $\begin{array}{llll}\text { Diakses } & \text { Rabu } & 21 & \text { Agustus }\end{array}$
} 


\section{Dasar Hukum}

Adapun dasar hukum penetapan tentang wajibnya memberikan nafkah kepada istri dalam Islam adalah sebagai berikut:

\section{Al Quran}

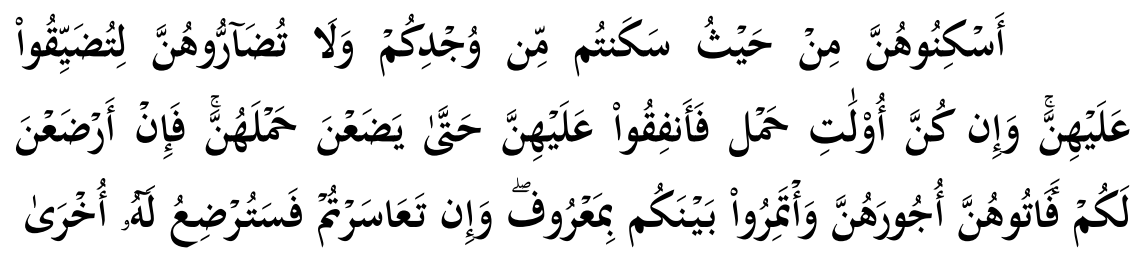

Terjemahnya:

"Tempatkanlah mereka (para isteri) di mana kamu bertempat tinggal menurut kemampuanmu dan janganlah kamu menyusahkan mereka untuk menyempitkan (hati) mereka. Dan jika mereka (isteri-isteri yang sudah ditalaq) itu sedang hamil, maka berikanlah kepada mereka nafkahnya hingga mereka bersalin, kemudian jika mereka menyusukan (anak-anak)mu untukmu maka berikanlah kepada mereka upahnya, dan musyawarahkanlah di antara kamu (segala sesuatu) dengan baik; dan jika kamu menemui kesulitan maka perempuan lain boleh menyusukan (anak itu) untuknya." (QS. Al Thalaq: 6) Dalam ayat ke enam surat al Thalaq ini Allah menjelaskan secara rinci tentang kewajiban seorang suami terhadap istri, bahkan apabila para istri telah diceraikan sekalipun, terutama ketika dalam keadaan hamil.

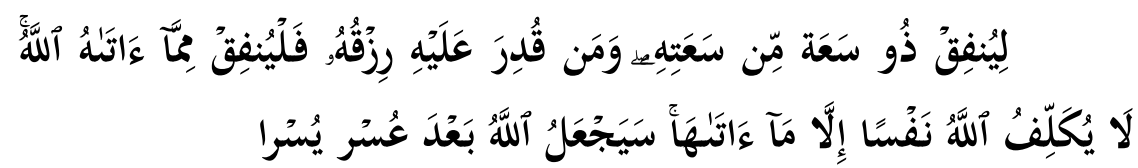

https://www.hukumonline.com/klinik/detail/ulasan/lt51ebe0b353993/batasanantara-nafkah-dan-uang-jajan.

Sangaji Jurnal Pemikiran Syariah dan Hukum 


\section{Terjemahnya:}

"Hendaklah orang yang mampu memberi nafkah menurut kemampuannya. Dan orang yang disempitkan rezekinya hendaklah memberi nafkah dari harta yang diberikan Allah kepadanya. Allah tidak memikulkan beban kepada seseorang melainkan sekedar apa yang Allah berikan kepadanya. Allah kelak akan memberikan kelapangan sesudah kesempitan." (QS. Al Thalaq: 7) Dalam ayat ini Allah menjelaskan tentang kewajiban seorang suami selaku kepala rumah tangga untuk menyediakan dan memberikan nafkah kepada orangorang yang menjadi tanggungannya sesuai dengan kemampuan tampa harus memaksakan diri.

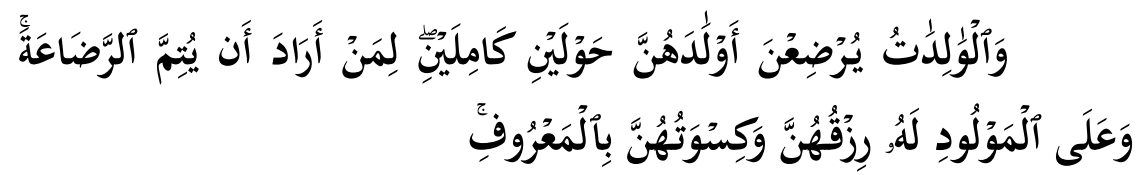

Terjemahnya:

"Para ibu hendaklah menyusukan anak-anaknya selama dua tahun penuh, yaitu bagi yang ingin menyempurnakan penyusuan. Dan kewajiban ayah memberi makan dan pakaian kepada para ibu dengan cara ma'ruf." (QS. Al Baqarah: 233) Demikian pula dalam ayat ini, Allah langsung menyebutkan secara sharih (pasti) tentang kewajiban siapa yang seharusnya memberi nafkah berupa makan dan pakaian kepada istri dan anak.

\section{Dari Hadits}

Dari Jabir mengisahkan bahwa Nabi Saw. bersabda:

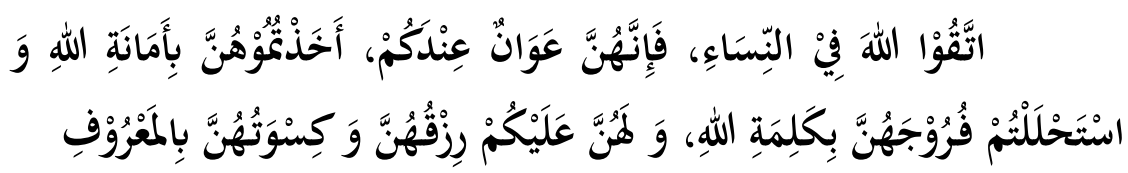


Artinya:

"Bertaqwalah kalian dalam masalah wanita. Sesungguhnya mereka ibarat tawanan di sisi kalian. Kalian ambil mereka dengan amanah Allah dan kalian halalkan kemaluan mereka dengan kalimat Allah. Mereka memiliki hak untuk mendapatkan rezki dan pakaian dari kalian" (HR. Muslim, Abu Dawud dan al Tirmidzi) Dalam hadits ini, Rasul menjelaskan tentang hak seorang istri kepada suami atau kewajiban suami terhadap istri, yaitu memenuhhi kebutuhan para istri berupa pakaian.

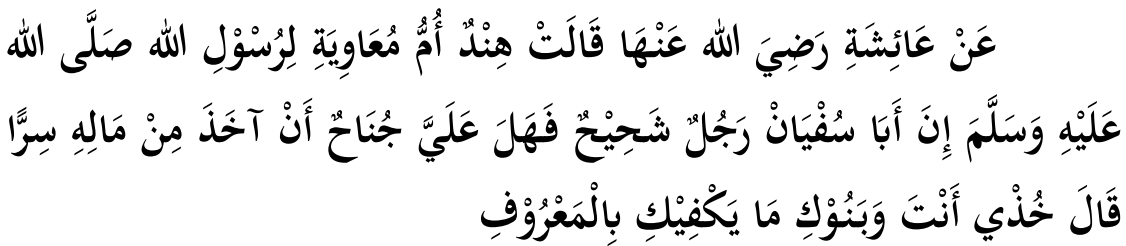

Artinya:

Dari 'Aisyah Ra.: Hindun, ibu dari Mu'awiyah berkata kepada Rasulullah Saw.: "Sesungguhnya Abu Sufyan adalah seorang yang kikir. Apakah dibenarkan bila aku mengambil dari hartanya secara sembunyi-sembunyi?" Maka Beliau bersabda: "Ambillah buatmu dan anak-anakmu sekedar apa yang patut untuk mencukupi kamu." (HR. Al Bukhari dan Muslim) Berdasarkan dalil ini dinyatakan bahwa nafkah suami kepada istri merupakan kewajiban yang pasti berdasarkan al Quran, sunnah, dan ijma'. Kewajiban suami menafkahi istri di mulai sejak terlaksananya akad sah pernikahan antara dirinya dan istrinya. Kewajiban menafkahi tetap berlaku sekalipun sang istri adalah seorang perempuan kaya atau punya penghasilan sendiri. ${ }^{8}$

${ }^{8}$ Ibnu al Qayyim al Jauziyyah. 1994. Zadu al Ma'ad. Cetakan V. Bairut: Muassasah al Risalah. Hlm. 505-509.

Sangaji Jurnal Pemikiran Syariah dan Hukum 


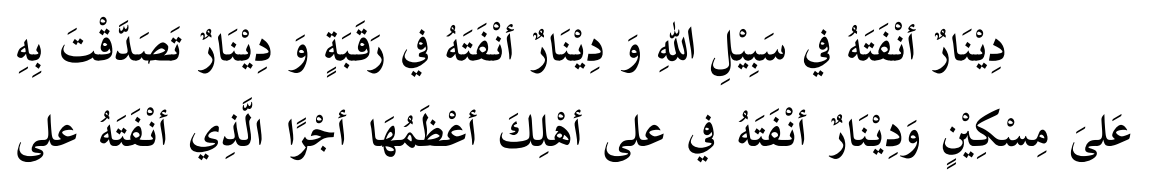

أهْلِكَ

Artinya:

"Dinar yang engkau infakkan di jalan Allah, dinar yang engkau infakkan untuk membebaskan budak, dinar yang engkau sedekahkan kepada orang miskin, dan dinar yang engkau nafkahkan kepada keluargamu, pahala yang paling besar adalah dinar yang engkau nafkahkan untuk keluargamu." (HR. Muslim, Ahmad dan Baihaqi) Demikian pula dengan hadits ini, Rasul menjelaskan tentang besarnya pahala bagi seorang suami yang memberi nafkah kepada para istri-istri.

\section{Sebab-Sebab Nafkah}

Berdasarkan beberapa dalil yang telah disebutkan di atas, maka para ulama fikih menyimpulkan bahwa sebab-sebab seseorang mendapatkan nafkah adalah sebagai berikut: ${ }^{9}$

1. Zaujiyyah (Pernikahan)

Penyebab pertama seseorang mendapatkan hak untuk dinafkahi adalah karena ikatan pernikahan yang sah menurut Islam walaupun tidak sah menurut undangundang atau peraturan pemerintah. Maka apabila syarat ini terpenuhi, wajib atas suami memberi nafkah kepada istri yang ta'at, baik berupa makanan, pakaian, tempat tinggal maupun perkakas rumah tangga dan kebutuhan lainnya sesuai dengan masing-masing lingkungan dan kekuatan suami. Hal ini sebagaimana dalam firman Allah surat al Thalaq ayat 7 .

9 Ahmad Rajafi. 2018. Reinterpretasi Makna Nafkah dalam Bingkai Islam Nusantara. Jurnal Al Ihkam V0lume 13 Nomor 1 Juni 2018. Hlm. 106. 
2. Qarabah (Hubungan Kekerabatan)

Penyebab kedua seseorang mendapatkan nafkah adalah adanya hubungan kekerabatan. Namun dalam hal kekerabatan ini terjadi perbedaan pendapat dari para ulama; ${ }^{10}$

a) Malikiyah menilai kerabat yang wajib mendapatkan nafkah adalah hubungan orang tua dan anak (al walid wa al walad).

b) Syafi'iyah menilai kerabat dalam hubungan orang tua dan anak dan hubungan cucu dan kakek (ushul dan furu').

c) Hanafiyah menilai kerabat yang dimaksud adalah dalam konteks mahramiyah (orang yang haram dinikahi), tidak hanya terbatas ushul dan furu', sehingga meliputi kerabat kesamping (hawasyiy), dan dzwil arham.

d) Hanabilah memahami kerabat dalam konteks hubungan waris fardh dan ashabah, meliputi ushul furu', hawasy, dan dzawil arham yang berada pada jalur nasab.

Syarat wajibnya nafkah ayah atau ibu kepada anaknya apabila anak masih kecil dan miskin, atau besar dan miskin namun tidak kuat berusaha. Kewajiban ini juga berlaku untuk anak ketika kedua orang tuanya tidak lagi kuat berusaha dan tidak memiliki harta. Merujuk pendapat pemberian nafkah anak kepada orang tua menurut madzhab Hanafi dan Syafi'i bahwa ketidakmampuan bekerja tidak merupakan syarat kewajiban memberikan nafkah kepada ayah dan kepada kakek. Namun Anak tetap wajib memberikan nafkah kepada ayah dan kakek. Sedangkan orang-orang selain

10 Wahbah al Zuhailî. 2002. Al Fiqhu al Islami wa Adillatuhu. Cetakan X. Suriah: Dar al Fikr. Hlm. 84-85.

Sangaji Jurnal Pemikiran Syariah dan Hukum 
ayah dan kakek yang sanggup bekerja, tidak ada kewajiban memberikan nafkah. ${ }^{11}$

3. Milk (Kepemilikan Terhadap Budak)

Dan penyebab terakhir seseorang mendapatkan nafkah adalah milk (Kepemilikan Terhadap Budak). Pada bagian ini, pembacaan kekinian dibutuhkan dalam memaknai kata kepemilikan (al-milk). Karena status budak saat ini sudah tidak lagi digunakan, maka arah pemaknaan kerabat pada konteks kepemilikian dapat diarahkan pada hal-hal yang berada dalam perlindungannya, seperti asisten rumahtangga, hewan atau tumbuhan yang dipelihara, anakanak yatim yang berada dalam tanggungannya, dan lainlain.

Berdasarkan semua keterangan tersebut, ulama sepakat untuk menempatkan suami sebagai pihak yang dibebankan kewajiban nafkah kepada istri dan anak-anaknya. Ismail Haqqi menegaskan bahwa secara eksplisit, kemutlakan kewajiban nafkah dibebankan kepada suami dipahami dari petunjuk dalam QS. Al Nisa' ayat 34, yang menginformasikan keistimewaan laki-laki dibandingkan wanita disebabkan salah satu faktornya adalah nafkah. ${ }^{12}$

Dan menurut Ibnu Hazm kewajiban suami untuk menafkahi istri terjadi sejak akad nikah, baik suami yang mengajaknya hidup serumah atau tidak atau istri masih dalam buaian atau berbuat nusyuz, kaya atau kafir, mempunyai orang tua atau sudah yatim, gadis atau janda, semua itu disesuaikan dengan keadaan dan kesangguapan suami. Namun para ulama

11 Muhammad Jawal Mughniyah. 1996. Al Figh ala al Madzahib al Khamsah, Terj. Masykur A.B. dkk. Cetakan II. Jakarta: PT. Lentera Basritama. Hlm. 433.

12 Ahmad Rajafi. 2018. Reinterpretasi Makna Nafkah dalam Bingkai Islam Nusantara. Jurnal Al Ihkam Volume 13 Nomor 1 Juni 2018. Hlm. 107. 
madzhab berpendapat bahwa istri yang melakukan nusyuz tidak berhak atas nafkah. ${ }^{13}$

\section{E. Macam-Macam Nafkah}

Sebagaimana dijelaskan di awal, bahwa secara umum nafkah terbagi menjadi dua macam: ${ }^{14}$

1. Nafkah Primer (Wajib)

Jenis nafkah yang primer (wajib), yaitu segala sesuatu yang dibutuhkan oleh sang istri serta keluarganya. Termasuk kategori nafkah wajib ini (tanpa ada perselisihan ulama) meliputi kebutuhan utama, seperti makanan, minuman, pakaian dan tempat tinggal, perhiasan serta sarana-sarana dan peralatan yang dibutuhkan istri untuk memenuhi kebutuhan utamanya, juga pemenuhan kebutuhan biologisnya. Semua itu wajib dipenuhi oleh suami.

2. Nafkah Sekunder (Sunnah)

Adapun kebutuhan selain yang disebutkan di atas adalah merupakan kebutuhan sunnah, seperti biaya pengobatan dan pengadaan pembantu rumah tangga. (terdapat silang pendapat di kalangan ulama) Mayoritas ahli fikih berpendapat, biaya pengobatan isteri tidak wajib bagi suami. Demikian juga dengan pengadaan pembantu rumah tangga, tidak wajib bagi suami, kecuali jika hal itu (memberikan pembantu rumah tangga) sudah menjadi satu hal yang lumrah dalam keluarga sang istri, ataupun di kalangan keluarga-keluarga lain di kaumnya.

13 Sayyid Sabiq. 1981. Fiqh Sunnah Juz 7, Terj. Mohammad Thalib. Bandung: Al Ma'arif. Hlm. 85.

14 Ibnu Rozali. 2017. Konsep Memberi Nafkah bagi Keluarga dalam Islam. Intelektualita: Volume 06 Nomor 02 Tahun 2017. Hlm. 197. Lihat juga: Umar Sulaiman. 1997. Ahkamuz Zawaj. Dar Al Nufasa'. Hlm. 94.

Sangaji Jurnal Pemikiran Syariah dan Hukum 
Namun yang penting harus diperhatikan, pengadaan pembantu rumah tangga ini juga tidak terlepas dari kesanggupan suami untuk memenuhinya. Jika tidak mampu memberikan pembantu rumah tangga untuk istrinya, maka tidak wajib bagi suami untuk mengadakannya, karena Allah tidak membebani seseorang di luar kesanggupannya.

\section{F. Kadar Nafkah}

Kewajiban memberikan nafkah kepada kerabat dan keluarga adalah merupakan kewajiban ketiga dari seorang suami (lelaki) setalah membayar mahar (walaupun pada hakikatnya mahar diberikan sebelum menikah/akad dilaksanakan) dan berlaku adil kepada istri (apabila suami berpoligami). Dan terhadap batasan atau kadar pemberian nafkah tersebut, sebagaimana dalam mahar yang tidak ada batasan pastinya, maka demikian pula nafkah; tidak memiki batasan pasti. Oleh karena itu terjadi silang pendapat ulama terkait hal ini.

Sebab terjadinya silang pendapat antara para ulama ini adalah tidak disebutnya batasan mahar dalam firman Allah Swt.

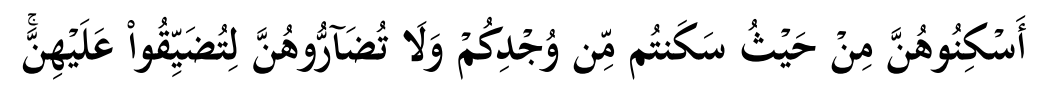

Terjemahnya:

“Tempatkanlah mereka (para isteri) di mana kamu bertempat tinggal menurut kemampuanmu dan janganlah kamu menyusahkan mereka untuk menyempitkan (hati) mereka." (QS. Al Thalaq: 6)

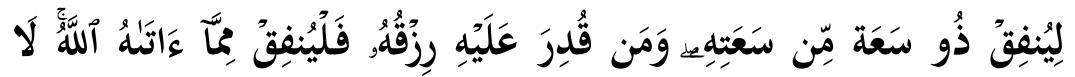

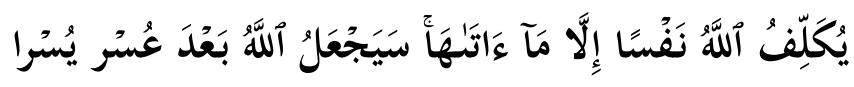




\section{Terjemahnya:}

"Hendaklah orang yang mampu memberi nafkah menurut kemampuannya. Dan orang yang disempitkan rezekinya hendaklah memberi nafkah dari harta yang diberikan Allah kepadanya. Allah tidak memikulkan beban kepada seseorang melainkan sekedar apa yang Allah berikan kepadanya. Allah kelak akan memberikan kelapangan sesudah kesempitan." (QS. Al Thalaq: 7)

Imam al Qurthubi berpendapat bahwa firman Allah (ليُنْفقُ) maksudnya adalah; hendaklah suami memberi nafkah kepada istrinya, atau anaknya yang masih kecil menurut ukuran kemampuan baik yang mempunyai kelapangan atau menurut ukuran miskin andaikata suami adalah orang yang tidak berkecukupan. Jadi ukuran nafkah ditentukan menurut keadaan orang yang memberi nafkah, sedangkan kebutuhan orang yang diberi nafkah ditentukan menurut kebiasaan

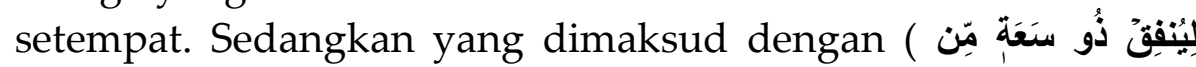
سَتَّنَهِ adalah bahwa perintah untuk memberi nafkah tersebut ditujukan kepada suami bukan terhadap istri. Adapun maksud

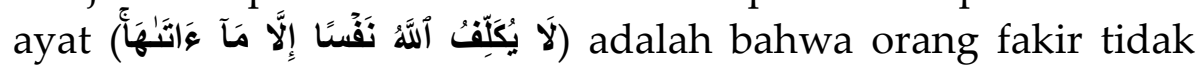
dibebani untuk memberi nafkah layaknya orang kaya dalam memberi nafkah. ${ }^{15}$

Sedangkan Imam Muhammad Ali al Sayis bahwa ayat (

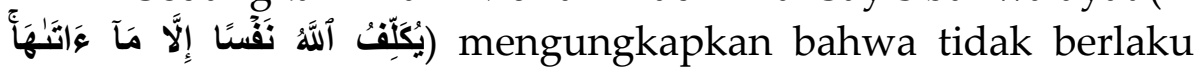
fasakh disebabkan karena suami tidak sanggup memberi nafkah kepada istrinya. Sebab ayat ini mengandung maksud bahwa bila seseorang tidak sanggup memberi nafkah karena kondisinya yang tidak memungkinkan disebabkan kemiskinannya, Allah Swt. tidak memberatkan dan

15 Jumni Nelli. 2017. Analisis Tentang Kewajiban Nafkah Keluarga Dalam Pemberlakuan Harta Bersama. Al Istinbath: Jurnal Hukum Islam Volume 2 Nomor 1 2017. Hlm. 32-33. Lihat juga: Muhammad al-Qurtubi. 1985. Al Jami' li Ahkam al Quran Juz XVIII. Beirut: Dar-al Ihya li Tirkah al Arabi. Hlm. 170.

Sangaji Jurnal Pemikiran Syariah dan Hukum 
membebaninya supaya memberi nafkah dalam kondisi tersebut. ${ }^{16}$

Namun menurut Jumhur ulama, ketidakmampuan suami membayar nafkah istri bukan berarti kewajibannya membayar nafkah gugur sama sekali, tetapi tetap menjadi hutang bagi suami yang harus di bayar ketika telah mampu, bahkan menurut Mazhab Syafi'i dan Hanbali, apabila suami tidak mampu sama sekali membayar nafkah, istri boleh meminta fasakh. Namun, menurut Mazhab Hanafi dan Maliki, suami yang tidak mampu membayar nafkah istri tidak boleh dipisahkan (diceraikan). Menurut Mazhab Hanafi, nafkah yang belum dibayarkan suami yang tidak mampu menjadi utang baginya yang harus dibayarkan ketika telah mampu. Bahkan, menurut Mazhab Maliki, karena suami tidak mampu membayar nafkah istri, maka selama ketidakmampuan kewajiban nafkah gugur dari suami. ${ }^{17}$

Lalu bagaimana dengan suami yang sebenarnya mampu memberikan nafkah, namun tidak menunaikannya? Mufid Abdullah menjelaskan: ${ }^{18}$

\section{Keengganan suami membayar nafkah sedangkan mampu.}

Apabila suami enggan membayar nafkah kepada istri, sedangkan telah menentukan nafkah istri atau hakim telah menetapkan nafkah wajib yang harus dibayarkannya, maka menurut ulama fikih hakim berhak menjual harta

16 Jumni Nelli. 2017. Analisis Tentang Kewajiban Nafkah Keluarga Dalam Pemberlakuan Harta Bersama. Al Istinbath: Jurnal Hukum Islam Volume 2 Nomor 1 2017. Hlm. 33. Lihat juga: Muhammad Ali al Sayyis. 1984. Tafsir Ayat al Ahkam Terjemahan. Bandung: PT. Al Ma'arif. Hlm. 298.

17 Subaidi. 2014. Konsep Nafkah Menurut Hukum Perkawinan Islam. ISTI'DAL; Jurnal Studi Hukum Islam, Volume 1 Nomor 2 Juli-Desember 2014. Hlm. 160-161.

18 Subaidi. 2014. Konsep Nafkah Menurut Hukum Perkawinan Islam. ISTI'DAL; Jurnal Studi Hukum Islam, Volume 1 Nomor 2 Juli-Desember 2014. Hlm. 160. 
tersebut secara paksa dan membayarkan nafkah istrinya sesuai dengan kebutuhannya. Apabila harta suami yang mampu itu tidak diketahui dan istrinya menuntut kepada hakim, maka hakim boleh memenjarakannya sampai membayar nafkah istri tersebut.

\section{Benar-benar tidak mampu.}

Namun apabila ternyata suami itu memang tidak memiliki harta, maka tidak boleh dipenjarakan sekalipun istri mengajukan gugatan kepada hakim karena Allah Swt. menyatakan apabila seseorang dalam kesulitan maka harus ditunggu sampai ia berkelapangan (QS. Al Thalaq:7).

Mengenai kadar mahar ini juga, terjadi silang pendapat antara para imam madzhab: ${ }^{19}$

1. Menurut Imam Syafi'i ukuran nafkah bagi orang miskin dan orang yang berada dalam kesulitan adalah satu mud. ${ }^{20}$ Bagi orang yang berada dalam kemudahan adalah dua mud. Jika diantara keduanya adalah satu setengah mud.

2. Menurut Imam Abu Hanifah bagi orang yang dalam kemudahan memberikan tujuh sampai delapan dirham tiap bulannya, sedangkan orang yang dalam kesulitan memberikan empat sampai lima dirham perbulanya.

3. Menurut Imam Malik bahwa besarnya nafkah tidak ditentukan berdasarkan ketentuan syara', tetapi berdasarkan keadaan masing-masing suami istri, dan ini akan berbedabeda berdasarkan perbedaan tempat, waktu, dan keadaan.

4. Menurut Hanabilah (pengikut Imam Hambali), sebagaimana yang dikutip oleh Ibnu Rozali, dimana kadar nafkah di ukur sesuai dengan kondisi suami-isteri. Jika keduanya termasuk Hlm. 518.

19 Ibnu Rusyd. 1998. Bidayatul Mujtahid. Cetakan I. Beirut: dar al Jil.

20 Satu mud adalah besar cakupan penuh dua telapak tangan ukuran normal yang digabungkan. Atau: 1 sha' = 4 mud. 1 sha' kira-kira 3 kg. $1 / 2$ sha' = 2 mud atau kira- kira $1 \frac{1}{2} \mathrm{~kg}$. Maka $1 \mathrm{mud}=0,75 \mathrm{~kg}$ atau $3 / 4 \mathrm{~kg}$.

Sangaji Jurnal Pemikiran Syariah dan Hukum 
golongan yang dimudahkan rejekinya oleh Allah (artinya sama-sama berasal dari keluarga berada), maka wajib bagi suami memberi nafkah dengan kadar yang sesuai dengan keadaan keluarga masing-masing. Jika keduanya berasal dari keluarga miskin, maka kewajiban suami memberi nafkah sesuai dengan keadaan masing-masing juga. Namun, jika kedua suami istri berasal dari keluarga yang berbeda tingkat ekonominya, maka kewajiban suami adalah memberikan nafkah sesuai dengan kadar keluarga kalangan menengah. ${ }^{21}$

\section{G. Kesimpulan}

Dari penjelasan singkat di atas, diambil beberapa kesimpulan bahwa:

1. Nafkah adalah kewajiban mutlak bagi seorang suami setelah menikah, bahkan walaupun bercerai, suami tetap wajib memberikan nafkah kepada mantan istri selama masa iddah, terutama apabila setelah masa perceraian diketahui mantan istri memiliki anak dalam kandungannya.

2. Seorang suami yang tidak membayarkan nafkah kepada istri, maka menurut hukum fikihnya, istri boleh melaporkannya kepada hakim dan menjual asetnya secara paksa untuk diserahkan kepada istri. Namun apabila tetap pada pendiriannya, maka dipenjarakan sampai menyerahkan nafkah yang telah ditentukan.

3. Kewajiban seorang suami memberikan nafkah bersifat kondusif, artinya dengan melihat keadaan sang suami. Apabila sang suami adalah orang yang berada, maka nafkah yang diberikan sesuai keadaannya, demikian sebaliknya.

21 Ahmad Rajafi. 2018. Reinterpretasi Makna Nafkah dalam Bingkai Islam Nusantara. Jurnal Al Ihkam Volume 13 Nomor 1 Juni 2018. Hlm. 104. 


\section{Daftar Pustaka}

Muhammad, Husein. 2001. Fiqh Perempuan. Yogyakarta: LKis.

Dahlan, Abdul Aziz. 1996. Ensklopedi Hukum Islam. Jakarta: PT. Ichtiar Baru.

Ali, Muhammad al Sayyis. 1984. Tafsir Ayat al Ahkam Terjemahan. Bandung: PT. Al Ma'arif.

Rajafi, Ahmad. 2018. Reinterpretasi Makna Nafkah dalam Bingkai Islam

Nusantara. Jurnal Al Ihkam Volume 13 Nomor 1 Juni 2018.

Mughniyah, Muhammad Jawal. 1996. Al Figh ala al Madzahib al

Khamsah, Terj. Masykur A.B. dkk. Cetakan II. Jakarta: PT.

Lentera Basritama.

Yayasan Lajnah Istiqomah Surakarta. 2004. Nafkah Untuk Sang Isteri. Majalah As-Sunnah Edisi 02/Tahun VIII/1424 H/2004 M.

Al Qurtubi, Muhammad. 1985. Al Jami' li Ahkam al Quran Juz XVIII. Beirut: Dar-al Ihya li Tirkah al Arabi.

Ibnu al Qayyim al Jauziyyah. 1994. Zadu al Ma'ad. Cetakan V. Bairut: Muassasah al Risalah.

Nelli, Jumni. 2017. Analisis Tentang Kewajiban Nafkah Keluarga Dalam

Pemberlakuan Harta Bersama. Al Istinbath: Jurnal Hukum Islam Volume 2 Nomor 12017.

Rusyd, Ibnu. 1998. Bidayatul Mujtahid. Cetakan I. Beirut: dar al Jil.

Depdiknas, Tim Pusat Bahasa. 2008. Kamus Bahasa Indonesia. Jakarta: Pusat Bahasa Departemen Pendidikan Nasional.

Bahri, Syamsul. 2015. Konsep Nafkah Dalam Hukum Islam. Kanun Jurnal Ilmu Hukum Nomor 66 Th. XVII Agustus 2015.

Abdurrahman. 1992. Perkawinan dalam Syari'at Islam. Cetakan I. Jakarta: Rineka Cipta.

Subaidi. 2014. Konsep Nafkah Menurut Hukum Perkawinan Islam. ISTI'DAL; Jurnal Studi Hukum Islam, Volume 1 Nomor 2 Juli-Desember 2014.

Syarifuddin, Amir. 2001. Hukum Perkawinan Islam di Indonesia.

Cetakan II. Jakarta: Prenada Media.

Sangaji Jurnal Pemikiran Syariah dan Hukum 
Al Zuhailî, Wahbah. 2002. Al Fiqhu al Islami wa Adillatuhu. Cetakan X. Suriah: Dar al Fikr.

Rozali, Ibnu. 2017. Konsep Memberi Nafkah bagi Keluarga dalam Islam. Intelektualita: Volume 06 Nomor 02 Tahun 2017.

Sulaiman, Umar. 1997. Ahkamuz Zawaj. Dar Al Nufasa'.

Al Rafi'I, Salim bin Abdu al Ghani. 2002. Ahkam al Ahwal al Syakhshiyyah li al Muslimin fi al Gharb. Beirut: Dar Ibn Hazm Dahlan, Abdul Aziz. 1996. Ensklopedi Hukum Islam. Jakarta: PT. Ichtiar Baru.

Sabiq, Sayyid. 2002. Fiqhu al Sunnah. Cetakan II. Kairo: Dar al Fikr. Tri Jata Ayu Pramesti. 2013. Batasan Antara Nafkah dan Uang Jajan. Diakses $\quad$ Rabu $21 \quad$ Agustus 2013. https://www.hukumonline.com/klinik/detail/ulasan/lt51ebe 0b353993/batasan-antara-nafkah-dan-uang-jajan. 